Article

\title{
Aqueous Partition of Methanolic Extract of Dicranopteris linearis Leaves Protects against Liver Damage Induced by Paracetamol
}

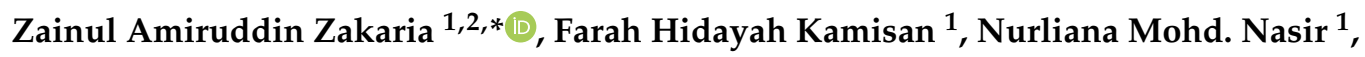 \\ Lay Kek Teh ${ }^{2}$ and Mohd. Zaki Salleh ${ }^{2}$ \\ 1 Department of Biomedical Sciences, Faculty of Medicine and Health Sciences, Universiti Putra Malaysia, \\ Serdang 43400, Selangor, Malaysia; lavandula88@yahoo.com (F.H.K.); liananasir89@gmail.com (N.M.N.) \\ 2 Integrative Pharmacogenomics Institute (I-PROMISE), Faculty of Pharmacy, Universiti Teknologi MARA, \\ Puncak Alam 42300, Selangor, Malaysia; tehlaykek2016@gmail.com (L.K.T.); \\ zakisalleh_mzs@gmail.com (M.Z.S.) \\ * Correspondence: zaz@upm.edu.my; Tel.: +603-89472111; Fax: +603-89472537
}

Received: 6 September 2019; Accepted: 11 October 2019; Published: 4 December 2019

\begin{abstract}
This study aimed to determine the antioxidant and hepatoprotective activities of semi-purified aqueous partition obtained from the methanol extract of Dicranopteris linearis (AQDL) leaves against paracetamol (PCM)-induced liver intoxication in rats. The test solutions, AQDL (50, 250 , and $500 \mathrm{mg} / \mathrm{kg}$ ), were administered orally to rats $(n=6)$ once daily for seven consecutive days followed by the hepatotoxicity induction using $3 \mathrm{~g} / \mathrm{kg}$ PCM (p.o.). Blood was collected for serum biochemical parameters analysis while the liver was collected for histopathological examination and endogenous antioxidant enzymes analysis. AQDL was also subjected to antioxidant determination and phytochemical analysis. Results obtained show that AQDL possessed high total phenolic content (TPC) value and remarkable radical scavenging activities. AQDL also significantly $(p<0.05)$ reduced the liver weight/body weight (LW/BW) ratio or serum level of ALT, AST, and total bilirubin while significantly $(p<0.05)$ increase the level of superoxide dismutase (SOD) and catalase (CAT) without affecting the malondialdehyde (MDA) in the liver indicating its hepatoprotective effect. Phytoconstituents analyses showed only the presence of saponins and triterpenes, but lack of flavonoids. In conclusion, AQDL exerts hepatoprotective activity via its high antioxidant potential and ability to modulate the endogenous enzymatic antioxidant defense system possibly via the synergistic action of saponins and triterpenes.
\end{abstract}

Keywords: Dicranopteris linearis; hepatoprotective; free radical scavenging activity; endogenous antioxidant enzymes; saponins; triterpenes; phenolic derivatives

\section{Introduction}

Drug-induced liver injury (DILI) is an infrequent but potentially life-threatening, undesirable drug reaction. It is the most common reason for drug withdrawal from the pharmaceutical market due to its association with significant adverse effects, morbidity, and mortality. A number of drugs, including bromfenac and troglitazone, have been removed from the market because of DILI [1]. DILI is responsible for the majority of acute liver failure cases and is now the leading cause for liver transplantation among patients. For example, DILI is accountable for about $10 \%$ of all adverse drug reactions in the United States (USA). Estimates of the annual incidence of DILI are reported to be as high as 14-24 cases/100,000 individuals and approximations show that almost 44,000 patients per year will develop DILI [2]. 
One of the important drugs related to DILI is paracetamol (PCM), a drug commonly utilized worldwide for its antipyretic or analgesic properties [3]. PCM is easily accessible in various formulations as an over-the-counter medication reflected by the fact that it is regularly consumed by over 60 million Americans on a weekly basis, making it the most widely utilized analgesic and antipyretic in the USA [4]. PCM has been reported to be one of the most common pharmaceutical products which cause DILI. Hepatic injury and subsequent hepatic failure due to both intentional and non-intentional overdose of PCM has affected patients for decades and remains a global issue [3]. PCM accounts for more than $50 \%$ of overdose-related acute liver failure and approximately $20 \%$ of the liver transplant cases [5]. Moreover, around 30,000 patients are admitted to hospitals every year for treatment of PCM hepatotoxicity in the USA. Mortality rates have been approximated at $0.4 \%$ in overdose patients, translating to 300 deaths annually in the USA [3].

According to the United States Food and Drug Administration (USFDA), PCM is considered non-toxic to an adult if consumed up to $1000 \mathrm{mg}$ every $4-6 \mathrm{~h}$, not to exceed $4000 \mathrm{mg}$ day-1, for no longer than 10 days [6]. At therapeutic levels, PCM is principally metabolized in the liver via the processes of glucuronidation and sulphation to unreactive metabolites with a small fraction undergoes bioactivation via a process mediated by cytochrome P450 (CYP450) to form reactive toxic electrophiles known as $\mathrm{N}$-acetyl-p-benzoquinoneimine (NAPQ1). NAPQ1 is then rapidly deactivated by an intracellular natural antioxidant known as glutathione (GSH). However, an overdose of PCM will result in the rise of toxic NAPQI metabolite generation, which extensively depletes the hepatocellular GSH level [7]. Excessive NAPQ1 production will lead to oxidative stress, which may exceed the antioxidant defense system, particularly GSH, resulting in the reduction of protective physiological moieties and decrease in repair capacity resulting in increased susceptibility of the liver to oxidative stress. With regard to the mechanism of action, these toxic metabolites will covalently bind to macromolecules in the vital biomembranes ensuing extensive propagation of the alkylation as well as peroxidation processes that alter cellular proteins, provoke oxidative stress, and cause damages to mitochondria leading to hepatocyte death. Other than that, NAPQ1 also induces lipid oxidation and alters the homeostasis of calcium. Membrane lipid peroxidation is directly related to the depletion of tissue GSH (an intracellular antioxidant) leading to the altered functional integrity of these structures, and if the damage is severe, it could be fatal [8]. Membrane lipid peroxidation may lead to alteration in membrane fluidity and permeability, enhanced rates of protein degradation, and ultimately hepatocytes death and liver injury. The concentration of intracellular GSH, therefore, is the key determinant of membrane integrity and the extent of toxicant-induced hepatic cell injury. The vital roles of reactive oxygen species (ROS) in the cellular damage are widely investigated and it has been suggested that the covalent binding of ROS, as well as reactive intermediates to macromolecules, could likely contribute to the severe harmful drug reactions. There are several studies that suggest the generation of reactive metabolites and free radicals from hepatotoxic drugs. Based on the above explanation, several main causes of the hepatotoxic reactions by drugs are elevated ROS generation, oxidative stress, and suppressed immune responses [9].

Currently, management of DILI, particularly of PCM-induced hepatotoxicity, is still a challenge to the modern medicine and controversial because the available pharmacological interventions, either conventional or synthetic drugs, are inadequate and occasionally cause serious side effects, which include being carcinogenic in long term use $[10,11]$. The increasing numbers of patients with liver dysfunction due to overwhelming usage of alcohol and drugs has paved the path for researchers to search for potential sources of new therapeutic agents for the prevention of DILI [12,13]. These plants are rich in triterpenes, flavonoids, or polyphenols, which have been now established as powerful hepatoprotective and chemopreventive agents in experimental liver-injury cell and animal models. Furthermore, as oxidative stress has been proven to play a major role in DILI, compounds with antioxidant activity might plausibly be good agents to reduce DILI [9]. The dietary nature, easy availability and less adverse reactions of medicinal plants provide them an extra edge over other candidates as supplements [14]. The basis behind the protection provided by the medicinal plants is hypothesized to be through their 
ability to remove free radicals from the cellular environment and therefore provide protection against ROS mediated damage to membrane lipids and macromolecules. Other than that, the protective potential of medicinal plants could also be attributed to their phytoconstituents ability to enhance endogenous antioxidants such as GSH and SOD biosynthesis/bioactivity, as well as to interact with various cytochrome P450 isoforms and to inhibit the entry of toxins to the cells [11]. It is envisaged that plant-based natural products will not only lower the risk of DILI but also provide an alternative solution to cure DILI.

One of the plants proven to possess medicinal values of remarkable antioxidant and anti-inflammatory activities is Dicranopteris linearis L. (family Gleicheniaceae) [15-17]. Known as "Resam" to the Malay, D. linearis is a fern widely distributed in Malaysia. Although not many traditional uses of this plant were recorded in Malay folklore medicine, its leaves were used as tonic or poultice to reduce body temperature $[15,16]$. Scientifically, D. linearis extracts have been reported to exert antinociceptive [15,16,18], antipyretic [16], anticancer [19,20], cytotoxic [17], hepatoprotective [21-25], and chemopreventive [26] activities. With regard to the hepatoprotective activity of $D$. linearis, preliminary studies using the chloroform, aqueous and methanol extracts of $D$. linearis leaf have successfully proven these extracts ability to attenuate PCM- and carbon tetrachloride-induced hepatotoxicity [21,22,24]. Further analyses by Kamisan et al. [23] revealed that the methanol extract of $D$. linearis leaf (MEDL) possessed remarkable antioxidant activity when assessed using the 2, 2-diphenyl-1-picrylhydrazyl (DPPH)- and superoxide anion-radical scavenging assays, oxygen radical absorbance capacity (ORAC) test and contained high total phenolic content (TPC) value, while Zakaria et al. [25] successfully demonstrated the ability of MEDL to enhance the endogenous antioxidant activity in PCM-induced hepatotoxic rats.

Although several known bioactive compounds have been identified from MEDL [23,25] using the high pressure liquid chromatography (HPLC) and ultra-high pressure liquid chromatography-electrospray ionization coupled with high resolution mass spectrometry (UHPLC-ESI/HRMS) approaches, it is not possible to directly foretell the character of bioactive compounds that really contribute to the hepatoprotective effect of $D$. linearis. This could be due to the fact that methanol, being the solvent system for soaking $D$. linearis leaves, has the ability to dissolve all types of bioactive compounds regardless of their polarity. Therefore, attempt was made to partition the MEDL using several solvents of different polarity to obtain the petroleum ether, ethyl acetate, and aqueous partitions, which represent non-polar, intermediate polar and highly polar types of bioactive compounds, respectively. Since there is a need to ascertain the effectiveness of each partition to attenuate liver injury, all partitions were subjected to the preliminary screening against the PCM-induced hepatotoxic effect in rats. Based on the preliminary findings (data not shown), the present study was designed to explore the hepatoprotective potential of the aqueous partition (AEDL) using the same animal models as reported by Zakaria et al. [25].

Taking these findings into consideration, the present study was designed to partition the MEDL sequentially with petroleum ether, ethyl acetate, and distilled water, and the aqueous partition of MEDL (AQDL) was subjected to hepatoprotective study against the PCM-induced liver injury in rats.

\section{Materials and Methods}

\subsection{Plant Material and Preparation of Methanol Extract D. Linearis (MEDL)}

The wildly grown leaves of D. linearis were collected around the area of Serdang, Selangor, Malaysia, between February and March 2012. The leaves have been previously identified and a voucher specimen (SK 1987/11) has been deposited at the Herbarium of the Institute of Bioscience, Universiti Putra Malaysia (UPM).

The leaves were washed with water to remove dirt and then dried in an oven at $40{ }^{\circ} \mathrm{C}$ for two weeks. During the drying time, the leaves were periodically turned over to provide uniform drying. The dried leaves obtained were ground to a coarse powder using a mill machine (CGOLDENWALL, 
China). Methanol extract of $D$. linearis (MEDL) was prepared as previously described in detail by Kamisan et al. [23]. Briefly, $160 \mathrm{~g}$ of powdered leaves were soaked in absolute methanol (1:20 (w/v)) for $72 \mathrm{~h}$ at room temperature and this procedure was repeated for three times.

\subsection{Preparation of Aqueous Partitions of MEDL ( $A Q D L)$}

The preparation of semi-purified aqueous partition was carried out according to the similar procedure described elsewhere [27]. About $20 \mathrm{~g}$ of the dried MEDL was suspended in $1000 \mathrm{~mL}$ of methanol (MeOH; Fisher Scientific, UK), and then $200 \mathrm{~mL}$ of distilled water was added. The aqueous $\mathrm{MeOH}$ extract was transferred into a $2000 \mathrm{~mL}$ separatory funnel and $700 \mathrm{~mL}$ of petroleum ether (PE; Fisher Scientific, UK) was then added. The mixture was vehemently shaken and then left for $24 \mathrm{~h}$ to allow the mixture to separate into two-phase immiscible liquid solutions. The lower phase supernatant, which represents PE partition, was collected while the upper layer supernatant was further partitioned using new PE for another two times. All collected PE supernatants were pooled together, filtered using the Whatman No. 1 filter paper and then concentrated using the rotary evaporator (Buchi Rotavapor $囚 R 210 / 215)\left(40^{\circ} \mathrm{C}\right.$; under reduced pressure (204 mbar)) to obtain the PE partition of MEDL (PEDL). Then, the residue of mixture solution was partitioned with ethyl acetate (EA; Fisher Scientific, UK) using the same partitioning procedure as described for PE to obtain the EA partition of $D$. linearis (EADL). The remaining upper layer residue was then subjected to further partitioning using ethyl acetate as described for PE partition and evaporated to obtain the EA partition of MEDL (EADL). Lastly, the remaining residual supernatant of aqueous $\mathrm{MEOH}$ solution was subjected to freeze-drying process to obtain the aqueous partition of MEDL (AQDL). AEDL was kept at $-4{ }^{\circ} \mathrm{C}$ until further use while the other partitions were kept at $-80^{\circ} \mathrm{C}$ for future use.

\subsection{Determination of the Antioxidant Activity of AQDL}

\subsubsection{Total Phenolic Content}

Total phenolic content (TPC) of AQDL was verified according to the slightly modified procedure of Singleton and Rossi [28] as described in detail by Kamisan et al. [23]. Briefly, AEDL, at the concentration of $1 \mathrm{mg} / \mathrm{mL}$, was mixed at room temperature with $80 \%$ methanol containing $1 \%$ hydrochloric acid and $1 \%$ distilled water and placed on a shaker set at $200 \mathrm{rpm}$ for $2 \mathrm{~h}$. The mixture was then centrifuged at $2817 \times g$ for $15 \mathrm{~min}$ to obtain the supernatant, which was mixed at the volume of $200 \mu \mathrm{L}$ with $400 \mu \mathrm{L}$ $(0.1 \mathrm{~mL} / 0.9 \mathrm{~mL})$ of Folin-Ciocalteu reagent and permitted to stand for $5 \mathrm{~min}$ at room temperature. Subsequently, $400 \mu \mathrm{L}$ of sodium bicarbonate $(60 \mathrm{mg} / \mathrm{mL})$ solution was added and the mixture was left to stand for $90 \mathrm{~min}$ at room temperature before the absorbance was read at $725 \mathrm{~nm}$ using a spectrophotometer. The level of TPC in the samples, expressed in terms of gallic acid equivalent (GAE) (mg GAE/g) dry extract, was measured based on the calibration curve created using the gallic acid standard optical density. The concentration of phenolics $(\mathrm{mg} / \mathrm{mL})$ was determined from the calibration line based on the measured absorbance.

\subsubsection{2-Diphenyl-1-Picrylhydrazyl (DPPH) Radical Scavenging Assay}

The free-radical scavenging potential of AQDL was determined using the modified method of Blois [29] as described by Kamisan et al. (2014). The partition in the concentration ranging from $3.13 \mu \mathrm{g} / \mathrm{mL}$ to $200 \mu \mathrm{g} / \mathrm{mL}$ was prepared from the stock solution $(1 \mathrm{mg} / \mathrm{mL})$. Briefly, a mixture of $50 \mu \mathrm{L}$ of AQDL, $50 \mu \mathrm{L}$ DPPH ( $1 \mathrm{mM}$ in ethanolic solution) and $150 \mu \mathrm{L}$ absolute ethanol (AR grade) was added in a 96-well microtiter plate and shaken for $15 \mathrm{~s}$ at $500 \mathrm{rpm}$. The plate was then kept at room temperature for $30 \mathrm{~min}$ followed by the measurement of absorbance at $520 \mathrm{~nm}$. These procedures were carried out in triplicate. Based on the absorbance recorded, the concentration of DPPH radical was measured based on the given equation:

$$
\text { DPPH scavenging effect }(\%)=\left[\left(A_{O}-A_{X}\right) /\left(A_{O}-A_{I}\right)\right] \times 100 \text {, }
$$


where $A_{O}$ is the absorbance of negative control, $A_{I}$ is the absorbance of positive control, and $A_{X}$ is the absorbance of the sample.

The $\mathrm{IC}_{50}$ value was calculated from the linear part of the graph of the inhibition of DPPH radical [30]. Data analysis was done by using Graph pad PRISM V5.01.

\subsubsection{Superoxide Anion Radical Scavenging Assay}

The superoxide anion radicals scavenging action of AQDL was determined based on the modified procedure of Liu et al. [31] as described in detail by Kamisan et al. [23]. According to this modified procedure, the superoxide radicals were generated in phenazine methosulphate-nicotinamide adenine dinucleotide (PMS-NADH) systems through the oxidation of NADH and measured based on the reduction of nitroblue tetrazolium (NBT). Briefly, the reaction mixture containing the superoxide radicals was prepared by mixing $3 \mathrm{~mL}$ of Tris- $\mathrm{HCl}$ buffer $(16 \mathrm{mM}, \mathrm{pH}$ 8) containing $1 \mathrm{~mL}$ of NBT $(50 \mu \mathrm{M}), 1 \mathrm{~mL}$ NADH $(78 \mu \mathrm{M})$ and AQDL $(25-50 \mu \mathrm{g})$ with $1 \mathrm{~mL}$ of phenazine methosulphate (PMS) solution $(10 \mu \mathrm{M})$. The reaction mixture was then incubated at $25^{\circ} \mathrm{C}$ for $5 \mathrm{~min}$ followed by the absorbance measurement at $560 \mathrm{~nm}$ using a spectrophotometer (UV-vis 1700, Shimadzu, Japan). Changes in the absorbance were compared between the AQDL-treated reaction mixtures against blank control or L-ascorbic acid as the positive control, and a decrease in the recorded absorbance indicates increasing superoxide anion scavenging activity. The percentage inhibition of superoxide anion production was evaluated using the following equation:

Inhibition of superoxide anion generation $(\%)=\left[1-\left(\mathrm{A}_{\mathrm{T}} / \mathrm{A}_{\mathrm{C}}\right)\right] \times 100$,

where $A_{C}$ was the absorbance of the blank control and $A_{T}$ was the absorbance in the presence of AQDL or positive control.

\subsubsection{Oxygen Radical Absorbance Capacity (ORAC) Test}

The antioxidant capacity of AQDL was measured using the slightly modified oxygen-radical absorbance-capacity (ORAC) assay [32] as described in detail by Kamisan et al. [23]. Briefly, a peroxyl-radical generator was prepared daily by mixing 2,2-azobis (2-amidinopropane) dihydrochloride (AAPH) with $10 \mathrm{~mL}$ of $75 \mathrm{mM}$ phosphate buffer (pH 7.4). On the other hand, $1 \mathrm{mM}$ of sodium fluorescein stock solution was prepared by dissolving it in $75 \mathrm{mM}$ phosphate buffer ( $\mathrm{pH}$ 7.4) and stored in wrapping foil at $5{ }^{\circ} \mathrm{C}$. Prior to its usage, the sodium fluorescein stock solution was further diluted 1:100,000 with $75 \mathrm{mM}$ phosphate buffer (pH 7.4). Then, $150 \mu \mathrm{L}$ of working solution of sodium fluorescein was added with $25 \mu \mathrm{L}$ of Trolox or $25 \mu \mathrm{L}$ of AQDL into the blank or sample wells of the 96-well microplate, respectively, and allowed to equilibrate by incubating for $10 \mathrm{~min}$ at $37^{\circ} \mathrm{C}$. After equilibration, the wells containing the respective mixture solution were added with $25 \mu \mathrm{L}$ of $240 \mathrm{mM}$ AAPH solution to initiate the reactions. The fluorescence intensity of each well was then determined kinetically with data taken every $1 \mathrm{~min}$ for $3 \mathrm{~h}$ using the BMG Omega Fluostar Fluorescence Spectrophotometer (BMG LABTECH, Ortenberg Germany), which was equipped with an excitation filter of $485 \mathrm{~nm}$ and an emission filter of $520 \mathrm{~nm}$. ORAC values were calculated using the MARS Data Analysis Reduction Software.

\subsection{Determination of the Anti-Inflammatory Activity of AQDL}

\subsubsection{Lipoxygenase Assay}

The effect of lipoxygenase (LOX) in the modulation of AQDL-induced hepatoprotective activity was determined using the slightly modified in vitro LOX assay [33] as described in detail by Kamisan et al. [23]. Briefly, a mixture solution containing $160 \mathrm{~mL}$ of sodium phosphate buffer (0.1 M, pH 8.0), $10 \mathrm{~mL}$ of AQDL (dissolved in $\mathrm{MeOH}$ ), and $20 \mathrm{~mL}$ of soybean LOX solution was incubated for $10 \mathrm{~min}$ at $25{ }^{\circ} \mathrm{C}$. Then, $10 \mathrm{~mL}$ of sodium linoleic acid solution, which act as the 
substrate, was added to instigate the reaction wherein linoleic acid was enzymatically converted to (9Z,11E)-(13S)-13-hydroperoxyoctadeca-9,11-dienoate. This reaction leads to the change in absorbance, which was measured using the spectrophotometer at $234 \mathrm{~nm}$ over the period of $6 \mathrm{~min}$. All reactions were completed in triplicates in a 96-well microplate.

\subsubsection{Xanthine Oxidase Assay}

The effect of xanthine oxidase $(\mathrm{XO})$ in the modulation of AQDL-induced hepatoprotective activity was determined using the slightly modified in vitro XO assay [34] as described in detail by Kamisan et al. [23]. Briefly, a mixture solution containing $10 \mu \mathrm{L}$ of AQDL (dissolved in DMSO), $10 \mu \mathrm{L}$ of XO solution, and $130 \mu \mathrm{L}$ of potassium phosphate buffer $(0.05 \mathrm{M}, \mathrm{pH} 7.5)$ was prepared and incubated for $10 \mathrm{~min}$ at $25^{\circ} \mathrm{C}$. Then, $100 \mu \mathrm{L}$ of xanthine solution, which act as the substrate, was added to start the reaction wherein xanthine was enzymatically converted to uric acid and hydrogen peroxides. This reaction led to the change in absorbance, which was measured using the spectrophotometer at $295 \mathrm{~nm}$. All reactions were completed in triplicates in a 96-well microplate.

\subsection{Experimental Animals}

Male Sprague Dawley rats weighing between 180 and $200 \mathrm{~g}$ and 8-10 weeks old were obtained from the Animal Source Unit, Faculty of Veterinary Medicine (FVM), Universiti Putra Malaysia (UPM) and housed in the Animal House Unit, Faculty of Medicine and Health Sciences, UPM under the standardized environmental conditions for $48 \mathrm{~h}$ as described in detail by Kamisan et al. [23]. The study protocol of the present study has been approved by the Animal House and Use Committee, Faculty of Medicine and Health Sciences, UPM (Ethical approval no.: UPM/FPSK/PADS/BR-UUH/00449) as previously described [23].

\subsection{Hepatoprotective Assay}

The animals were randomly divided into six equal groups $(n=6)$ and fasted overnight prior to the experiment. Group 1 (Normal control) was pretreated (p.o) with vehicle (10\% of dimethyl sulfoxide (DMSO)); Group 2 (Hepatotoxic control) was also pretreated (p.o) with vehicle; Group 3 (Positive control) was pretreated (p.o.) with $200 \mathrm{mg} / \mathrm{kg}$ silymarin suspended in $1 \%$ carboxymethyl cellulose (CMC), and; Groups 4-6 (Test groups) were pretreated (p.o.) with 50, 250, and $500 \mathrm{mg} / \mathrm{kg}$ AQDL suspended in $10 \%$ DMSO, respectively. Each group of the rats received the respective dose of test solution orally once daily for 7 consecutive days and $3 \mathrm{~h}$ after the last administration of test solution on day 7; Group 1 was treated (p.o.) with 10\% DMSO whereas Groups 2-6 were treated (p.o.) with $3 \mathrm{mg} / \mathrm{kg}$ PCM. The rats' body weight was taken prior to and after the administration of test solutions, and once daily for the next 7 days prior to the PCM treatment. Forty-eight $h$ after the administration of PCM, rats from each of the groups were anesthetized by ketamine $(100 \mathrm{mg} / \mathrm{kg}$; intramuscular (i.m.)) and xylazine $(16 \mathrm{mg} / \mathrm{kg}$; i.m.), and blood was collected into heparinized bottles by cardiac puncture. Then the rats were euthanized by cervical dislocation and the liver was instantly removed, washed in ice-cold saline to remove the blood, and duly weighed. A segment from the midpoint lobe of the liver was conserved in $10 \%$ formalin solution for histological analysis. The remaining of the liver was promptly frozen in dry ice and stored at $-80^{\circ} \mathrm{C}$ for further endogenous antioxidant enzymes analysis. The experimental grouping of the rats is shown in Table 1.

\subsubsection{Biochemical Analysis of Collected Blood Samples}

For the biochemical analyses, the blood samples were separated by centrifuging at $3000 \mathrm{rpm}$ for $10 \mathrm{~min}$, and the plasma samples were aspirated off and frozen at $-80^{\circ} \mathrm{C}$ until use [23]. Later, the plasma samples were biochemically analyzed to determine the level of alanine aminotransferase (ALT), aspartate aminotransferase (AST), alkaline phosphatase (ALP), and total bilirubin (TB) using the Hitachi 902 Automatic Chemical Analyser (Hitachi, Minato-ku, Tokyo, Japan). 
Table 1. Experimental grouping of the rats used to study the hepatoprotective activity of AQDL against PCM-induced hepatotoxic rats.

\begin{tabular}{ccc}
\hline Group & Oral Pre-Treatment for 7 Days & 3 h after Last Treatment on 7th Day \\
\hline Normal control & $10 \%$ DMSO & $10 \%$ DMSO \\
\hline Intoxicated group & $10 \%$ DMSO & $3 \mathrm{mg} / \mathrm{kg} \mathrm{PCM}$ \\
\hline Positive control & $200 \mathrm{mg} / \mathrm{kg} \mathrm{silymarin}$ & $3 \mathrm{mg} / \mathrm{kg} \mathrm{PCM}$ \\
\hline \multirow{2}{*}{ Treatment } & $50 \mathrm{mg} / \mathrm{kg} \mathrm{AQDL}$ & $3 \mathrm{mg} / \mathrm{kg} \mathrm{PCM}$ \\
\cline { 2 - 3 } & $250 \mathrm{mg} / \mathrm{kg} \mathrm{AQDL}$ & $3 \mathrm{mg} / \mathrm{kg} \mathrm{PCM}$ \\
\hline & $500 \mathrm{mg} / \mathrm{kg} \mathrm{AQDL}$ & $3 \mathrm{mg} / \mathrm{kg} \mathrm{PCM}$ \\
\hline
\end{tabular}

2.6.2. Determination of the Activity of Antioxidant Enzymes (Superoxide Dismutase (SOD) and Catalase (CAT)) and Level of Malondialdehyde (MDA) in Liver Homogenates

Liver tissues were homogenized in cold phosphate buffer $(5 \mathrm{mM}, \mathrm{pH} 7.4)$ to give a $10 \%(\mathrm{w} / \mathrm{v})$ homogenate and then centrifuged at $4000 \mathrm{rpm}$ for $25 \mathrm{~min}$ at $4{ }^{\circ} \mathrm{C}$. Prior to the measurement of SOD, CAT, and MDA activities, protein concentration was determined using the Bradford method [35] with bovine serum albumin (BSA) used as the standard. Later, the supernatant of liver homogenate was subjected to the estimation of SOD and CAT activity and MDA level using the respective manufacturer's protocols provided within the commercial kits (Cayman Chemical Company, Ann Arbor, MI, USA).

\subsubsection{Histological Analysis of the Treated Liver}

The livers were routinely processed in an Automatic Tissue Processor (Leica TP1020, Nussloch, Germany), and then embedded in paraffin wax with Leica EG 1160 (Leica Microsystems, Nussloch, Germany). Then, the tissues were sectioned to a 5-6 mm thickness using a microtome (Leica RM2125 RTS, Nussloch, Germany) and then stained with hematoxylin and eosin dye using the Tissue- Tek Prisma- Ezs Autostainer (Sakura, Torrance, CA, USA). The stained section was then subjected to the microscopic examination using the light microscope (Olympus-CX31, Shinjuku, Tokyo, Japan). The liver sections were then scored and evaluated by a pathologist according to the severity of the hepatic injury as described by El-Beshbishy et al. [36].

\subsection{Analyses of Phytochemical Constituents of AQDL}

\subsubsection{Phytochemical Screening of AQDL}

AQDL was subjected to the qualitative phytochemical screening for the presence of saponins, steroids, flavonoids, triterpenes, tannins, and alkaloids according to procedures described by Ikhiri et al. [37].

\subsubsection{High-Performance Liquid Chromatography (HPLC) Analysis of AQDL}

The partition (AQDL) was subjected to HPLC analysis using the following HPLC system; Waters Delta 600 with 600 Controller equipped with Waters 996 photodiode array detector and a Phenomenex Luna column $(5 \mu \mathrm{m} ; 4.6 \mathrm{~mm}$ i.d. $\times 250 \mathrm{~mm})$ (Torrance, CA, USA). The procedures used were as reported by Zakaria et al. [38]. In brief, two types of eluants namely $0.1 \%$ aqueous formic acid (eluant A) and acetonitrile (eluant B) were used. The gradient elution was programmed so that the initial condition was 95\% A and 5\% B (acetonitrile) with a linear gradient reaching $25 \% \mathrm{~B}$ at $t=12 \mathrm{~min}$. After $10 \mathrm{~min}(t=22 \mathrm{~min})$, the gradient of $\mathrm{B}$ was decreased to $15 \%$ and sustained for $12 \mathrm{~min}(t=30 \mathrm{~min})$. Starting from $t=30 \mathrm{~min}$, the program was returned to the initial solvent composition at $t=35 \mathrm{~min}$. Millennium 32 Chromatography Software (Waters Co., Milford, MA, USA) was used to record and integrate the chromatograms at peak areas with the peak elution monitored at various wavelengths, namely 210, 254, 280, 300, 330, and $366 \mathrm{~nm}$. The verified chromatograms 
were analyzed, and the recorded retention times, peak areas, and UV spectra of main peaks were studied. The HPLC profiles of AQDL were also analyzed by comparing the chromatogram of AQDL against the respective chromatogram of several pure bioactive compounds available in the laboratory, namely fisetin, quercetin rutin, quercitrin, naringenin, genistein, pinostrobin, hesperetin, flavanone, $4^{\prime}, 5,7$-trihydroxyflavanone, 2,4,4'-trihydroxychalcone, dihydro quercetin or hesperetin at $254 \mathrm{~nm}$. Retention times for each of the peak of standard pure compounds were compared against the peaks of AQDL, and the similarity between these retention times and UV spectra information recorded indicated the presence of the particular bioactive compounds.

\subsection{Statistical Analysis}

Data were expressed as mean values \pm SD of six rats in each group. Statistical analysis was performed using one-way analysis of variance (ANOVA) followed by Dunnet's Multiple Comparison test with $p<0.05$ considered to be statistically significant. Statistical analysis was conducted using the Graph Pad Prism software version 5.

\section{Results}

\subsection{Extraction Yield of $A Q D L$}

Approximately $74.0 \mathrm{~g}$ of crude MEDL was partitioned using solvents of increasing polarity to obtain semi-purified petroleum ether (3.38 g), ethyl acetate (8.59 g), and aqueous (11.27 g) partitions of $D$. linearis. The aqueous partition of $D$. linearis (AQDL) was chosen to be further tested for its antioxidant, anti-inflammatory, and hepatoprotective potential.

\subsection{TPC Value, Free Radical Scavenging-, and Antioxidant-Activity of AQDL}

The TPC value and radical scavenging activities of AQDL are showed in Table 2. AQDL was also found to possess characteristics of a strong antioxidant agent indicated by the high TPC value (>100 mg GAEs/100 mg extract), remarkable DPPH- and superoxide-radical scavenging activities $(75 \%$ to $85 \%$ scavenging activity in comparison to the standard drug, $200 \mu \mathrm{g} / \mathrm{mL}$ ascorbic acid or $200 \mu \mathrm{g} / \mathrm{mL}$ SOD, respectively), and high ORAC value ( $>15,000 \mu \mathrm{mol} \mathrm{TE} / 100 \mathrm{~g}$ in comparison to the standard drug, $200 \mu \mathrm{g} / \mathrm{mL}$ Trolox).

Table 2. TPC and free radical scavenging activity of $200 \mu \mathrm{g} / \mathrm{mL}$ AQDL.

\begin{tabular}{|c|c|c|c|c|}
\hline Sample & $\begin{array}{l}\text { Total Phenolic } \\
\text { Content (TPC) }{ }^{1}\end{array}$ & $\begin{array}{l}\text { DPPH Radical } \\
\text { Scavenging (\%) }\end{array}$ & $\begin{array}{c}\text { Superoxide Scavenging } \\
(\%)\end{array}$ & $\begin{array}{l}\text { Total ORAC Value } \\
(\mu \mathrm{M} \text { TE/ } 100 \mathrm{~g})\end{array}$ \\
\hline Standard & Gallic acid (GAE) & Ascorbic acid (AA) & $\begin{array}{c}\text { Superoxide dismutase } \\
\text { (SOD) } \\
\left(6 \times 10^{-3} \mathrm{U} / \mathrm{ML}\right)\end{array}$ & Trolox standard curve \\
\hline AQDL & $193.5 \pm 14.8$ & $84.3 \pm 2.6$ & $79.0 \pm 2.5$ & $18997 \pm 1096$ \\
\hline
\end{tabular}

\subsection{Effect of AQDL against the LOX- and XO-Mediated Inflammatory Activity}

Table 3 shows the in vitro effect of AQDL against the in vitro LOX- and XO-mediated inflammatory activity. At $100 \mu \mathrm{g} / \mathrm{mL}$, AQDL induced a very low inhibitory effect on the LOX-mediated inflammatory activity ( $<20 \%$ inhibition) while failed to inhibit the XO-mediated inflammatory activity.

\subsection{In Vivo Hepatoprotective Activity of $A Q D L$}

The effect of AQDL on the body weight (BW), liver weight (LW), and LW/BW ratio; the level of serum biochemical parameters (serum ALT, AST, ALP, and TB); and the activity of endogenous antioxidant enzymes (SOD and CAT) or lipid peroxidation marker (MDA) in PCM-induced hepatotoxic 
rats are shown in Tables 4-6, respectively. In addition, the histopathological examination of the PCM-intoxicated liver tissues pretreated or non-pretreated with AQDL is shown in Figure 1.

Table 3. In vitro anti-inflammatory effect of $100 \mathrm{mg} / \mathrm{mL}$ AQDL assessed using the lipoxygenase and xantine oxidase assays.

\begin{tabular}{ccc}
\hline Sample & $\begin{array}{c}\text { Lipoxygenase } \\
\mathbf{( \% )}\end{array}$ & $\begin{array}{c}\text { Xanthine Oxidase } \\
\mathbf{( \% )}\end{array}$ \\
\hline Sample concentration & $100 \mathrm{mg} / \mathrm{mL}$ & $100 \mathrm{mg} / \mathrm{mL}$ \\
\hline AQDL & $16.5 \pm 1.3$ & $\mathrm{NA}$ \\
\hline
\end{tabular}

All values are expressed as mean \pm SEM. Note: $\mathrm{H}$, high $(71 \%$ to $100 \%) ; \mathrm{M}$, moderate ( $41 \%$ to $70 \%)$; $\mathrm{L}$, low ( $0 \%$ to $40 \%)$; NA, not active.

Table 4. Effect of AQDL on the percentage of liver weight/body weight (LW/BW) ratio in PCM-treated rats.

\begin{tabular}{ccccc}
\hline Treatment & Dose $\mathbf{( m g / k g )}$ & $\begin{array}{c}\text { Mean of Body } \\
\text { Weight, BW } \mathbf{( g )}\end{array}$ & $\begin{array}{c}\text { Liver Weight, } \\
\text { LW (g) }\end{array}$ & LW/BW (\%) \\
\hline Control & - & $208.7 \pm 5.6$ & $5.9 \pm 0.3$ & $2.8 \pm 0.1$ \\
DMSO + PCM & & $219.5 \pm 4.7$ & $9.7 \pm 0.9^{\mathrm{a}}$ & $4.4 \pm 0.4^{\mathrm{a}}$ \\
Silymarin + PCM & 200 & $200.0 \pm 4.7$ & $6.9 \pm 0.2^{\mathrm{b}}$ & $3.5 \pm 0.1^{\mathrm{b}}$ \\
& 50 & $166.2 \pm 7.8$ & $6.6 \pm 0.4^{\mathrm{b}}$ & $3.9 \pm 0.1$ \\
AQDL + PCM & 250 & $187.7 \pm 2.2$ & $8.0 \pm 0.3^{\mathrm{b}}$ & $4.2 \pm 0.2$ \\
& 500 & $189.8 \pm 4.7$ & $6.3 \pm 0.3^{\mathrm{b}}$ & $3.3 \pm 0.1^{\mathrm{b}}$ \\
\hline
\end{tabular}

Values are expressed as means \pm S.E.M. of six replicates. ${ }^{a}$ Significant different as compared to normal control, $p<0.05{ }^{\mathrm{b}}$ Significant different as compared to negative control, $p<0.05$.

Table 5. Effect of AQDL on serum level of ALT (U/L), AST (U/L), ALP (U/L), and total bilirubin $(\mu \mathrm{mol} / \mathrm{L})$.

\begin{tabular}{cccccc}
\hline Treatment & $\begin{array}{c}\text { Dose } \\
(\mathbf{m g} / \mathbf{k g})\end{array}$ & $\begin{array}{c}\text { ALT } \\
\mathbf{( U / L )}\end{array}$ & $\begin{array}{c}\text { AST } \\
\mathbf{( U / L )}\end{array}$ & $\begin{array}{c}\text { ALP } \\
\mathbf{( U / L )}\end{array}$ & $\begin{array}{c}\text { TB } \\
\text { (umol/L) }\end{array}$ \\
\hline Control & - & $15.83 \pm 2.9^{-}$ & $95.13 \pm 5.9$ & $115.7 \pm 7.0^{\mathrm{a}}$ & $0.5 \pm 0.2^{\mathrm{a}}$ \\
$\begin{array}{c}\text { DMSO + PCM } \\
\text { Silymarin + }\end{array}$ & & $1714 \pm 142.2^{\mathrm{a}}$ & $2266 \pm 340.4^{\mathrm{a}}$ & $330.0 \pm 42.4^{\mathrm{a}}$ & $4.1 \pm 0.8^{\mathrm{a}}$ \\
PCM & 200 & $474.5 \pm 82.2^{\mathrm{b}}$ & $690.9 \pm 146.6^{\mathrm{b}}$ & $195.5 \pm 11.1^{\mathrm{b}}$ & $2.3 \pm 0.3^{\mathrm{b}}$ \\
& 50 & $80.40 \pm 10.3^{\mathrm{b}}$ & $134.9 \pm 22.4^{\mathrm{b}}$ & $321.3 \pm 4.3$ & $0.9 \pm 0.3^{\mathrm{b}}$ \\
AQDL+ PCM & 250 & $908.4 \pm 172.9^{\mathrm{b}}$ & $1705 \pm 403.5^{\mathrm{b}}$ & $329.7 \pm 44.0$ & $1.2 \pm 0.5^{\mathrm{b}}$ \\
& 500 & $298.1 \pm 27.1^{\mathrm{b}}$ & $527.6 \pm 102.1^{\mathrm{b}}$ & $286.8 \pm 24.4$ & $1.7 \pm 0.3^{\mathrm{b}}$ \\
\hline
\end{tabular}

Values are expressed as means \pm S.E.M. of six replicates. ${ }^{a}$ Significant different as compared to normal control, $p<0.05 .{ }^{\mathrm{b}}$ Significant different as compared to negative control, $p<0.05$.

Table 6. Effects of AQDL on liver SOD, CAT, and MDA levels in PCM intoxicated rats.

\begin{tabular}{ccccc}
\hline Treatment & $\begin{array}{c}\text { Dose } \\
(\mathbf{m g} / \mathbf{k g})\end{array}$ & $\begin{array}{c}\text { SOD } \\
(\mathbf{U} / \mathbf{g} \text { tissue) }\end{array}$ & $\begin{array}{c}\text { CAT } \\
(\mathbf{U} / \mathbf{g} \text { tissue })\end{array}$ & $\begin{array}{c}\text { MDA } \\
(\boldsymbol{\mu M})\end{array}$ \\
\hline Control & - & $9.7 \pm 0.4$ & $114.8 \pm 1.6$ & $2.6 \pm 0.6$ \\
DMSO + PCM & & $4.0 \pm 0.1^{\mathrm{a}}$ & $92.9 \pm 1.9^{\mathrm{a}}$ & $5.0 \pm 0.6^{\mathrm{a}}$ \\
Silymarin + PCM & 200 & $12.0 \pm 0.2^{\mathrm{b}}$ & $109.5 \pm 4.7^{\mathrm{b}}$ & $2.6 \pm 0.3^{\mathrm{b}}$ \\
& 50 & $18.5 \pm 0.2^{\mathrm{b}}$ & $114.1 \pm 0.8^{\mathrm{b}}$ & $3.3 \pm 0.6$ \\
AQDL + PCM & 250 & $15.1 \pm 0.4^{\mathrm{b}}$ & $112.3 \pm 1.2^{\mathrm{b}}$ & $4.3 \pm 0.6$ \\
& 500 & $17.8 \pm 0.1^{\mathrm{b}}$ & $112.2 \pm 1.8^{\mathrm{b}}$ & $4.6 \pm 0.6$ \\
\hline
\end{tabular}

Values are expressed as means \pm S.E.M. of six replicates. ${ }^{a}$ Significant different as compared to normal control, $p<0.05{ }^{\mathrm{b}}$ Significant different as compared to negative control, $p<0.05$. 

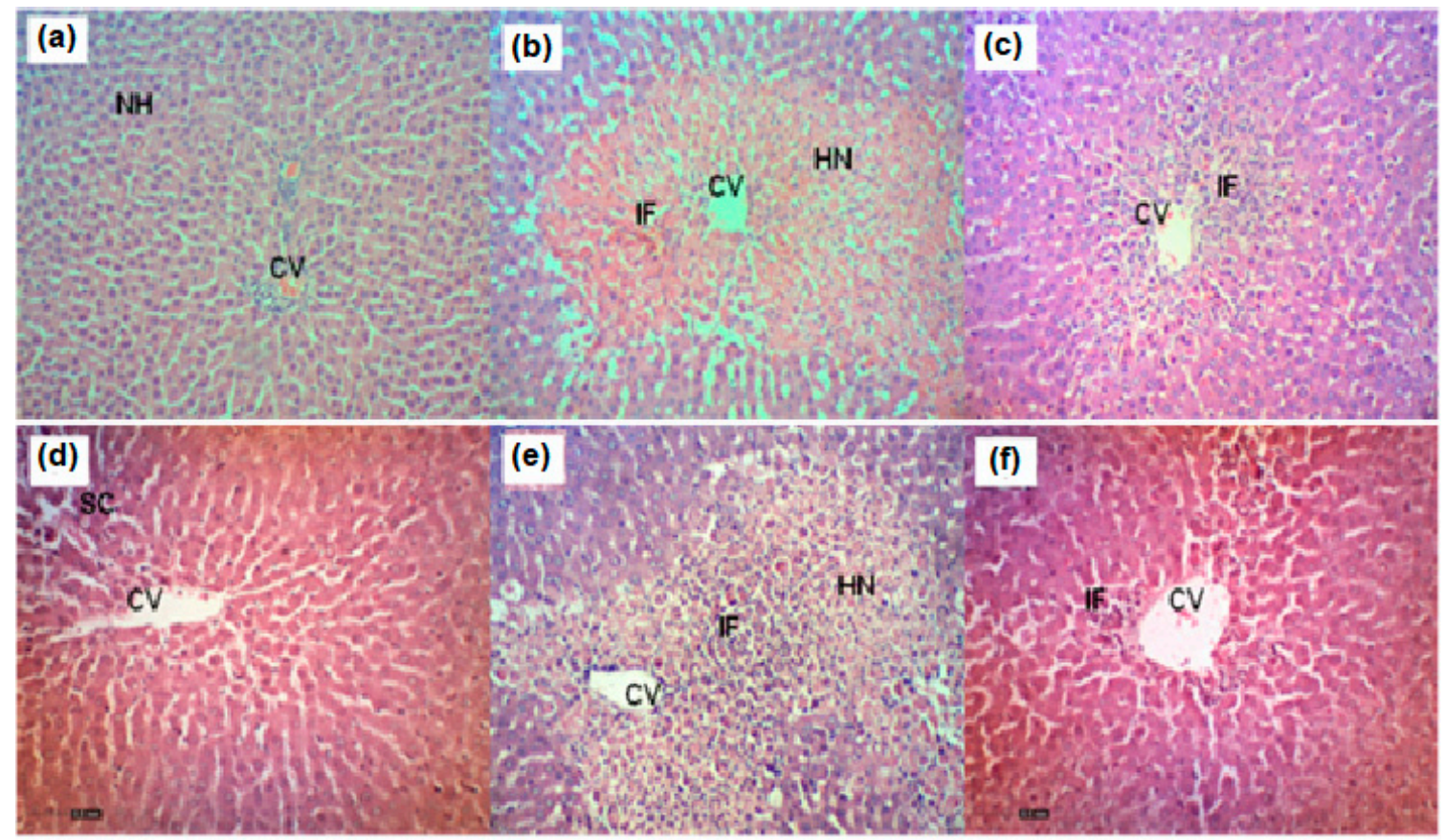

Figure 1. (a) Normal liver parenchyma. (b) Section of liver tissue treated with $3 \mathrm{~g} / \mathrm{kg}$ PCM (p.o) showing large area of hemorrhagic necrosis around centrilobular region; inflammatory cell infiltration was observed at the center of the necrotic foci. (c) Section of liver tissue pre-treated with $200 \mathrm{mg} / \mathrm{kg}$ silymarin followed by PCM showing preservation of normal hepatocytes. (d) Section of liver tissue pre-treated with $50 \mathrm{mg} / \mathrm{kg}$ AQDL followed by PCM showing mild sinusoidal congestion and cellular swelling. (e) Section of liver tissue pre-treated with $250 \mathrm{mg} / \mathrm{kg}$ AQDL followed by PCM showing moderate hemorrhagic necrosis in centrilobular region and presence of inflammatory infiltrate. (f) Section of liver tissue pre-treated with $500 \mathrm{mg} / \mathrm{kg}$ AQDL followed by PCM showing mild inflammatory infiltrate and mild cellular swelling. (H\&E staining, 100x magnification). $\mathrm{CV}=$ central vein. $\mathrm{IF}=$ inflammatory infiltrate. $\mathrm{HN}=$ hemorrhagic necrosis. $\mathrm{SC}=$ sinusoidal congestion. $\mathrm{S}=$ steatosis.

\subsubsection{Effect of AQDL on the Body Weight (BW), Liver Weight (LW), and the LW/BW Ratio of} PCM-Intoxicated Rats

From the results obtained, although there were no significant changes in their BW when compared to the normal group, the PCM-induced hepatotoxic rats demonstrated significant $(p<0.05)$ increases in their LW and LW/BW ratio, which was significantly $(p<0.05)$ reduced when pre-treated with all doses of AQDL or silymarin (Table 4).

\subsubsection{Effect of AQDL on the Serum Level of ALT, AST, ALP, and TB of PCM-Intoxicated Rats}

Moreover, the levels of serum ALT, AST, ALP, and total bilirubin were found to be abnormally high in PCM-intoxicated group indicating liver dysfunction and signified the injury to hepatocytes (Table 5). Interestingly, AQDL significantly $(p<0.05)$ reversed the increased in serum enzymes level induced by PCM suggesting its ability to hinder leakage of intracellular enzymes through its membrane stabilizing activity. In addition, the significant $(p<0.05)$ reduction in serum TB level following AQDL pre-treatment in PCM-intoxicated rats indicated the effectiveness of AQDL in returning the liver to its normal functional status (Table 5).

3.4.3. Effect of AQDL on the Activity of Endogenous Enzymatic Antioxidant System, Namely, SOD and CAT, of PCM-Intoxicated Rats

Incidentally, PCM intoxication caused significant $(p<0.05)$ decrease in SOD and CAT activities, and these effects were significantly $(p<0.05)$ reversed following the AQDL or silymarin pre-treatment 
(Table 6). However, the present study also shows that AQDL did not significantly $(p<0.05)$ affect the serum level of MDA, which was significantly $(p<0.05)$ increased following PCM intoxication.

\subsection{Histopathological Findings on the Effect of AQDL against the PCM-Intoxicated Liver Tissue Section}

Figure 1 shows the histopathological findings of PCM-intoxicated liver tissues with pre-treatment or without pretreatment with AQDL. PCM-intoxicated liver tissues (Figure 1b) demonstrated the most severe damage in hepatocyte architecture such as massive hemorrhagic necrosis around the centrilobular region, severe cytoplasmic vacuolation, broad infiltration of lymphocytes around the central vein and in the portal areas, loss of cellular boundaries, and ballooning degeneration in comparison to the liver tissue of normal control group (Figure 1a), which demonstrated the normal cellular architecture indicated by distinct hepatic cells that were radiantly arranged around the central vein, the hepatocytes with prominent nucleus and well-preserved cytoplasm, and the well-defined sinusoidal line. Interestingly, pre-treatment with silymarin (Figure 1c) or AQDL (Figure 1d-f) attenuated PCM toxic effect as indicated by the presence of a relatively normal lobular pattern with a mild degree of necrosis and lymphocyte infiltration observed. Table 7 shows the histopathological scoring of the liver section of PCM-induced hepatotoxic rats with or without pretreatment with AQDL. Overall, the histological findings corroborate well with the serum biochemical and endogenous antioxidant enzymes activities and further confirmed that AQDL has the ability to reduce the degree of PCM-induced liver injury.

Table 7. Effect of AQDL on the histopathological scoring of liver section of PCM-intoxicated rats.

\begin{tabular}{cccccc}
\hline Treatment & Dose $\mathbf{( m g} / \mathbf{k g})$ & Steatosis & Necrosis & Inflammation & Hemorrhage \\
\hline Control & - & - & - & - & - \\
DMSO + PCM & & + & +++ & ++ & + \\
Silymarin + PCM & 200 & - & + & - & - \\
AQDL + PCM & 50 & - & + & - & - \\
& 250 & + & ++ & + & - \\
\hline
\end{tabular}

\footnotetext{
The severity of various features of hepatic injury was evaluated based on those following scoring scheme: - normal,
}

+ mild effect, ++ moderate effect, +++ severe effect.

\subsection{Phytochemical Analyses of AQDL}

The qualitative phytochemical screening of AQDL revealed only the presence of saponins and triterpenes (Table 8). In addition, the HPLC analysis of AQDL at 210, 254, 280, 300, 330, and $366 \mathrm{~nm}$ revealed the phytoconstituents profiles of AQDL (Figure 2A). Two different peaks were detected at $366 \mathrm{~nm}$, namely, (i) peak 1, detected at 254-366 nm with the recorded retention time (RT) of approximately $19.311 \mathrm{~min}$, exerted the absorption peak (UV-vis spectral) of $264.9 \mathrm{~nm}$ for Band I and $347.0 \mathrm{~nm}$ for Band 2; and (ii) peak 2, detected at 254-366 nm with the recorded RT of approximately $19.925 \mathrm{~min}$, exhibited the UV-vis spectral at $227.2 \mathrm{~nm}$ (Band I) and $313.6 \mathrm{~nm}$ (band 2) (Figure 2A).

Table 8. Qualitative phytochemical screening revealed the phytoconstituents of AQDL.

\begin{tabular}{|c|c|c|c|c|c|c|c|}
\hline \multirow{2}{*}{ Sample } & \multicolumn{6}{|c|}{ Phytochemical Constituents } & \multirow{2}{*}{ Conclusion } \\
\hline & ALK & SAP & FLA & TAN & TTP & STR & \\
\hline AQDL & - & + & - & - & + & - & $\begin{array}{c}\text { Saponins and triterpenes } \\
\text { only detected. }\end{array}$ \\
\hline
\end{tabular}

ALK: Alkaloids; SAP: Saponins; FLA: Flavonoids; TAN: Tannins; TTP: Triterpenes; STR: Steroids; +: detected; -: not detected.

Furthermore, comparison of the detected peaks of AQDL at $366 \mathrm{~nm}$ with the peak of several pure flavonoid-based compounds showed that none of the peak of the standard flavonoids matched any of 
the peaks of AQDL. Figure 2B showed only a comparison between the chromatogram of AQDL [Peak 1 $(\mathrm{RT}=19.311 \mathrm{~min})$ or Peak $2(\mathrm{RT}=19.925 \mathrm{~min})]$ against the chromatogram of rutin $(\mathrm{RT}=20.395 \mathrm{~min})$ and quercetin $(\mathrm{RT}=27.472 \mathrm{~min})$.
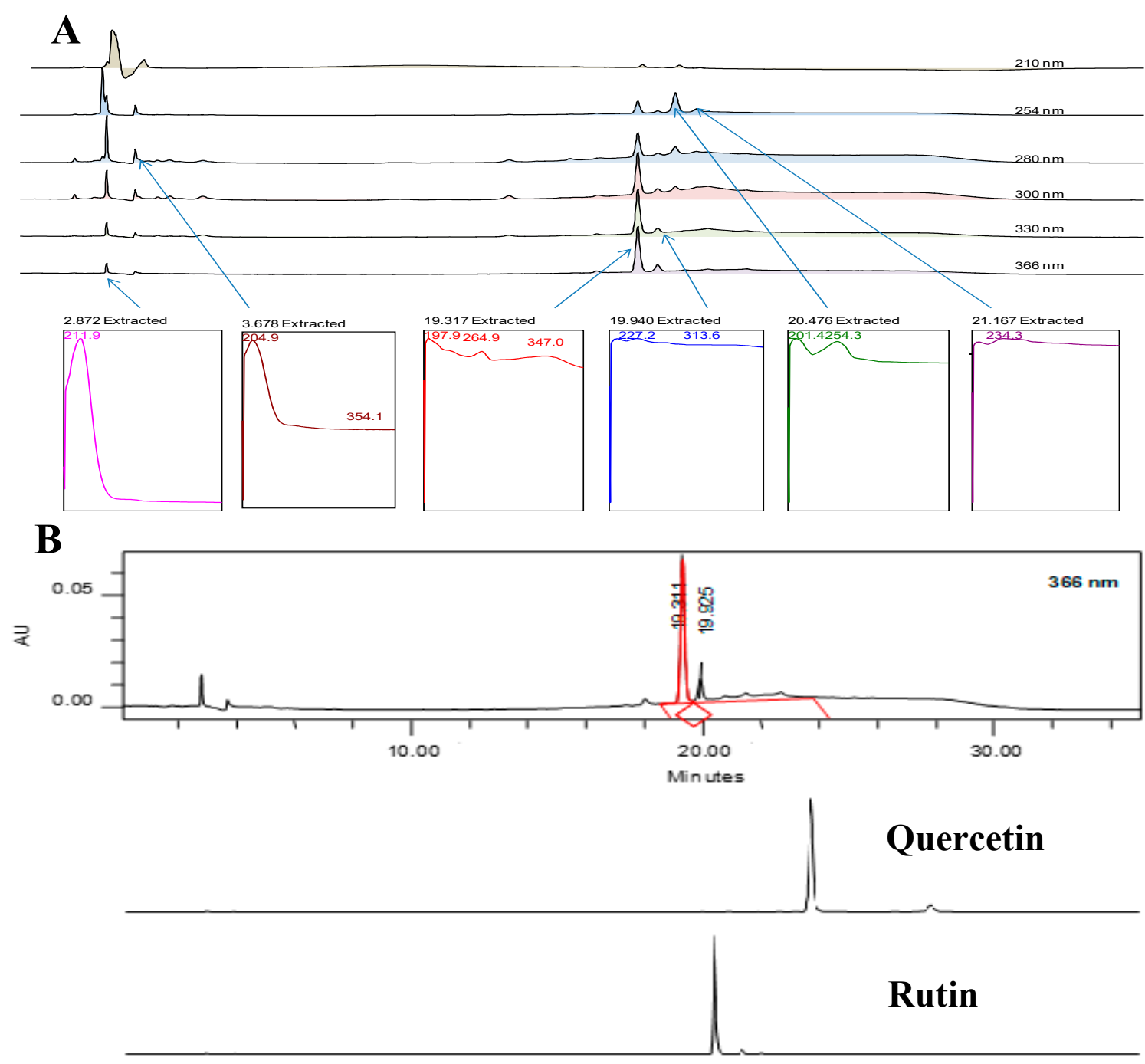

Figure 2. (A) HPLC profile of AQDL shows several detected peaks with their respective retention time and UV-vis spectral information at different wavelengths. Only two peaks were detected at $366 \mathrm{~nm}$, and only one peak ( $R T=19.327 \mathrm{~min}$ ) possessed the UV-vis spectral (Band A fall in the range of 310-350 nm; Band B fall in the range of 250-290 nm) that is a characteristic of flavonoid-based (flavones type) bioactive compound. (B) Comparison between the chromatogram of AQDL against the chromatograms of several pure flavonoids revealed that none of the flavonoids were present in the said partition. Only two chromatograms of pure flavonoids, namely, quercetin and rutin, were included for comparison with AQDL.

\section{Discussion}

Phenolics, the most extensive secondary metabolites in the plant kingdom, have received much interest as prospective natural antioxidants in terms of their abilities to act as both efficient radical scavengers and metal chelators [39]. The high TPC value of AQDL corresponded well with our previous finding [17] and further supported the report made by Lim and Lai [40] on the high TPC content of $D$. linearis, thus, could help to explain the remarkable radical scavenging activities demonstrated by AQDL. Although flavonoids and tannins were not detected during phytochemicals screening of AQDL, the high TPC value could be attributed to the presence of small number of flavonoids as detected 
during the HPLC analysis and/or possibly by the presence of derivatives of phenolic compounds such as phenolic acid esters and phenolic esters of triterpenoids [41-43]. Other than flavonoids or phenolic-based compounds, saponins themselves have also been reported to possess radical scavenging activity and antioxidant activity [44-46]. Based on the established reports associating oxidative stress as part of the mechanisms of liver injury [47], it is reasonable to suggest that the remarkable radical scavenging and antioxidant activities of AQDL contribute to its significant hepatoprotective activity. These activities of AQDL thwart the redox state precipitated intracellularly due to the action of NAPQ1 and hence ensure hepatoprotection against PCM-induced liver injury. The findings of this study corroborate the effect that was reported for MEDL [23,25].

Despite the good antioxidant activity, AQDL exerts low inhibitory effect in both in vitro LOX and XO inflammatory assay. The LOXs pathway is involved in the metabolism of leukotrienes and has been implicated in hepatic inflammation and liver damage [48]. Interestingly, further studies by Li et al. [49] revealed that inhibition of LOX pathway attenuates acute liver failure by inhibiting macrophage activation, while $\mathrm{Pu}$ et al. [50] demonstrated the critical role of 5-LO activity in PCM-induced liver injury by regulating paracetamol metabolism and oxidative stress. It was found that pharmacological inhibition of 5-LO in mice markedly ameliorated PCM-induced liver injury while inhibition of 5-LO induced hepatoprotective effect, which was associated with induction of the antitoxic phase II conjugating enzyme (sulfotransferase2a1), suppression of the pro-toxic phase I (CYP3A11), and reduction of the hepatic transporter (MRP3). The low inhibitory effect of AQDL against LOX activity suggested that AQDL did not exert hepatoprotective activity against PCM-induced intoxication via the inhibition of LOX-mediated inflammatory activity. This finding further corroborates the report made by Zakaria et al. [25] that MEDL also showed a low inhibitory activity against LOX-mediated inflammatory activity. Meanwhile, xanthine oxidase (XO) is an enzyme that generates ROS such as superoxide radicals and hydrogen peroxide when it catalyzes the oxidation of hypoxanthine to xanthine and can further catalyze the oxidation of xanthine to uric acid [51]. XO was further considered as a potential source of ROS in the liver after PCM overdose based partly on the ability of xanthine oxidase inhibitor, allopurinol, to attenuate the oxidative stress and liver injury in mice intoxicated with PCM [52]. However, further investigation by Williams et al. [53] has provided evidence that argues for a possible participation of xanthine oxidase, as a relevant source of ROS, in the pathophysiology of PCM-induced hepatotoxicity. However, according to Du et al. [54], it is obvious that the mechanism of liver protection is not simply the ability of allopurinol to inhibit xanthine oxidase or scavenge reactive oxygen but might involve alteration of the intracellular signaling pathways or up-regulation of the expression of cytoprotective genes. It was also suggested that mitochondria are the main source of ROS, which impairs mitochondrial function and is responsible for cell signaling resulting in cell death. Du et al. [54] also proposed that mitochondrial targeted antioxidants can be viable therapeutic agents against hepatotoxicity induced by PCM overdose, and re-purposing existing drugs to target oxidative stress and other concurrent signaling events can be a promising strategy to increase their potential application in patients with PCM overdose. Taking these findings and suggestions into consideration, it is plausible to suggest that AQDL did not modulate the $\mathrm{XO}$-mediated pathway as indicated by its failure to produce inhibitory effect when assessed using the XO-mediated inflammatory assay. Thus, it is possible that the ability of AQDL to attenuate PCM-induced hepatotoxic effect could be attributed to its ability to scavenge ROS synthesized in mitochondria. However, this suggestion needs further in-depth study before a conclusion could be made. Although the present findings on the lack of anti-inflammatory activities of AQDL against LOXand XO-mediated inflammation correspond well with the lack of effect of MEDL against LOX and XO actions [25], these observations seem to contradict the earlier reports on aqueous extract of $D$. linearis' remarkable anti-inflammatory activity [19]. However, this discrepancy might be explained by the fact that the anti-inflammatory activity of aqueous extract of $D$. linearis was assessed using the in vivo cyclo-oxygenase-2 (COX-2)-mediated inflammatory model indicating the ability of the extract to inhibit COX-2-mediated inflammation [55]. Interestingly, the involvement of COX-2 in PCM-induced liver 
intoxication has been reported by Reilly et al. [56], who demonstrated that COX-2, but not COX-1, was induced in livers of PCM-intoxicated mice. It is commonly agreed that the mode of action of PCM is the inhibition of prostanoid biosynthesis, particularly prostaglandins (PGs), via the COX-mediated pathway of arachidonic acid metabolism. COX-1 and COX-2 are bifunctional enzymes that work via, firstly, COX activity and, secondly, peroxidase activity. It was through the peroxidase action that prostaglandins-G2 (PGG2) was converted to prostaglandin H2 (PGH2). On the other hand, PGH2 is converted by various, cell specific enzymes into final PGs, prostacyclin and thromboxane, collectively known as prostanoids. Prostanoids bind to and activate the prostanoid receptors, a G-protein coupled receptors (GPCRs), to obtain a vast range of responses including sensitization to pain, inflammation and fever, immune and cardiovascular functions. It is well acknowledged that NSAIDs and the specific COX inhibitors interfere with the COX activity whereas PCM interferes with the peroxidase activity. Coincidently, Suciu et al. [57] have reported on the activation of a COX-mediated signaling pathway, predominantly the COX-2-prostanoid pathway, during PCM-induced liver injury. Hence, the ability of AQDL to attenuate PCM-induced intoxication could plausibly be attributed in part to its inhibitory action on the COX-2-prostanoid pathway that involved inhibition of the peroxidase action.

Excess consumption of PCM either accidentally or non-accidentally can cause acute liver intoxication, which, if not properly treated, results in liver damage [1-3]. This acute toxic effect results from PCM being metabolized by the liver to form a toxic electrophile called NAPQ1 that binds covalently to tissue macromolecules, possibly oxidizes lipids or the essential sulfhydryl groups (protein thiols) and changes the homeostasis of calcium [58]. Excessive production of reactive species can contribute to diminution of defensive physiological moieties, such as GSH and $\alpha$-tocopherol, resulting in damage to the macromolecules in imperative biomembranes and, finally, liver injury. Consequently, when there is liver injury, several enzymes, namely, ALT, AST, ALP, and molecules such as bilirubin and albumin, which are initially present in the cytoplasm, seep out into the blood stream [59]. Therefore, liver function can be evaluated by assessing the activities of serum ALT, AST, ALP, and bilirubin. In addition, according to Sharma et al. [60], the increase in serum level of ALP is due to its increase synthesis in the presence of increasing biliary pressure and reflects the pathological modification in biliary flow. In addition, verification of serum bilirubin also signifies an index for evaluation of hepatic function wherein any unusual increase in the levels of serum bilirubin point towards hepatobiliary-related ailments and severe disruption of hepatocellular function [61]. It is known that bilirubin is a metabolic product of hemoglobin and undergoes conjugation with glucuronic acid in hepatocytes to increase its solubility in water. Moreover, NAPQ1 actions also resulted in the decreased in the activity of endogenous enzymatic antioxidants such as SOD and CAT, which provide endogenous antioxidant defense by scavenging the superoxide anion to form hydrogen peroxide, therefore reducing the toxic effect caused by these radicals [8].

Enzymatic antioxidants such as SOD and CAT are involved in scavenging superoxide anion to form hydrogen peroxide, therefore reducing the toxic effect caused by these radicals. These enzymes are essential in the enzymatic antioxidant defense system, and declines in their activities may result in numerous toxic effects [62]. Natural antioxidants fortify the endogenous antioxidants defenses from ROS and reinstate the optimal balance by neutralizing reactive species [11]. The ability of AQDL to increase the hepatic SOD and CAT activities in PCM-intoxicated rats indicates that AQDL has the ability to diminish reactive free radicals, thereby reducing oxidative damage to the liver tissues by improving the activity of hepatic antioxidant enzymes.

Phytoconstituents of AQDL were investigated using the qualitative phytochemical screening and HPLC analysis. Based on the first assay, only saponins and triterpenes were detected in AQDL. This finding corroborates well the HPLC analysis, which revealed the presence of several small peaks with only one peak (Peak 1) suggested to be a flavonoid-based bioactive compound based on the UV-vis spectral recorded. Based on the characteristic UV-vis spectra of the two peaks detected at $366 \mathrm{~nm}$, it is believed that only peak 1 represents a flavonoid-based compound based on the UV-vis spectral recorded (Band $1=347.0 \mathrm{~nm}$; Band $2=264.9 \mathrm{~nm}$ ) $[63,64]$. The chromatograms also clearly revealed 
that AQDL contains: (i) a low number of flavonoid-based bioactive compounds indicated by only one major peak detected with UV-vis spectral that fall in the range of $254-366 \mathrm{~nm}$, and; (ii) a low content of flavonoid-based compounds as indicated by the presence of small size peak. These facts might explain why flavonoid was not detected during the qualitative phytochemical screening stage. It is believed that Peak 1 might possibly belong to the phenolic glycosides group particularly of the flavonol 3-O-glycosides group as reported by Raja et al. [65], Chen et al. [66], and Ponnusamy et al. [67]. Further phytoconstituents analyses need to be carried out and the possible bioactive compounds in AQDL need to identified. Overall, the phytochemical analyses revealed that the extract contained mainly saponins and triterpenes. Generally, the presence of phenolic-based compounds, saponins, and triterpenes were believed to contribute synergistically to the observed antioxidant and hepatoprotective activities of AQDL [68-70].

\section{Conclusions}

In conclusion, the present study suggests that AQDL possessed remarkable antioxidant activity and exerted hepatoprotective effect against PCM-induced intoxication partly via the activation of the endogenous antioxidant defense system and the presence of saponins, triterpenes and, possibly, phenolic derivatives. Overall, these findings could be used as a basis to further develop D. linearis as a hepatoprotective therapy for human usage.

Author Contributions: Conceptualization, Z.A.Z.; methodology, Z.A.Z. and M.Z.S.; software, L.K.T.; validation, Z.A.Z. and M.Z.S.; formal analysis, F.H.K. and N.M.N.; investigation, F.H.K. and N.M.N.; resources, Z.A.Z.; data curation, Z.A.Z. and F.H.K.; writing—original draft preparation, F.H.K., N.M.N., and L.K.T.; writing一review and editing, Z.A.Z. and M.Z.S.; visualization, Z.A.Z.; supervision, Z.A.Z. and M.Z.S.; project administration, Z.A.Z.; funding acquisition, Z.A.Z.

Funding: This research was funded by the Ministry of Higher Education (MOHE), Malaysia [Fundamental Research Grant Scheme (Reference no.: 04-01-18-1984FR)]. The APC was funded by the Research Management Center, Universiti Putra Malaysia, Malaysia.

Acknowledgments: The authors thanked the Faculty of Medicine and Health Sciences, UPM, Malaysia, for providing the facilities to carry out the experiment.

Conflicts of Interest: The authors declare no conflict of interest. The sponsors had no role in the design, execution, interpretation, or writing of the study.

\section{References}

1. Chang, C.Y.; Schiano, T.D. Review article: Drug hepatotoxicity. Aliment. Pharmacol. Ther. 2007, 25, $1135-1151$. [CrossRef]

2. Khoury, T.; Rmeileh, A.A.; Yosha, L.; Benson, A.A.; Daher, S.; Mizrahi, M. Drug induced liver injury: Review with a focus on genetic factors, tissue diagnosis, and treatment options. J. Clin. Transl. Hepatol. 2015, 3, 99-108.

3. Yoon, E.; Babar, A.; Choudhary, M.; Kutner, M.; Pyrsopoulos, N. Acetaminophen-induced hepatotoxicity: A comprehensive update. J. Clin. Transl. Hepatol. 2016, 4, 131-142.

4. Heard, K.; Green, J.L.; Bailey, J.E.; Bogdan, G.M.; Dart, R.C. A randomized trial to determine the change in alanine aminotransferase during 10 days of paracetamol (acetaminophen) administration in subjects who consume moderate amounts of alcohol. Aliment. Pharmacol. Ther. 2007, 26, 283-290. [CrossRef]

5. Hayward, K.L.; Powell, E.E.; Irvine, K.M.; Martin, J.H. Can paracetamol (acetaminophen) be administered to patients with liver impairment? Br. J. Clin. Pharmacol. 2015, 81, 210-222. [CrossRef]

6. Lee, W.M. Acetaminophen-related acute liver failure in the United States. Hepatol. Res. 2008, 38, S3-S8. [CrossRef]

7. Lee, W.M. Acetaminophen (APAP) hepatotoxicity—Isn't it time for APAP to go away? J. Hepatol. 2017, 67, 1324-1331. [CrossRef] [PubMed]

8. Jaeschke, H.; Ramachandran, A. Oxidant stress and lipid peroxidation in acetaminophen hepatotoxicity. React. Oxyg. Species 2018, 5, 145-158. [CrossRef] 
9. Singh, D.; Cho, W.C.; Upadhyay, G. Drug-induced liver toxicity and prevention by herbal antioxidants: An overview. Front. Physiol. 2016, 6, 363. [CrossRef] [PubMed]

10. Raschi, E.; De Ponti, F. Drug- and herb-induced liver injury: Progress, current challenges and emerging signals of post-marketing risk. World J. Hepatol. 2015, 7, 1761-1771. [CrossRef]

11. Azab, A.E.; Albasha, M.O. Hepatoprotective effect of some medicinal plants and herbs against hepatic disorders induced by hepatotoxic agents. J. Biotechnol. Bioeng. 2018, 2, 8-23.

12. Asadi-Samani, M.; Kafash-Farkhad, N.; Azimi, N.; Fasihi, A.; Alinia-Ahandani, E.; Rafieian-Kopaei, M. Medicinal plants with hepatoprotective activity in Iranian folk medicine. Asian Pac. J. Trop. Biomed. 2015, 5, 146-157. [CrossRef]

13. Yin, X.; Zhou, J.; Jie, C.; Xing, D.; Zhang, Y. Anticancer activity and mechanism of Scutellaria barbata extract on human lung cancer cell line. Life Sci. 2004, 7, 2233-2244. [CrossRef] [PubMed]

14. Yuan, H.; Ma, Q.; Ye, L.; Piao, G. The traditional medicine and modern medicine from natural products. Molecules 2016, 21, 559. [CrossRef] [PubMed]

15. Zakaria, Z.A.; Abdul Ghani, Z.D.F.; Nor, R.N.S.R.M.; Hanan Kumar, G.; Sulaiman, M.R.; Fatimah, C.A. Antinociceptive and asnti-inflammatory activities of Dicranopteris linearis leaves chloroform extract in experimental animals. Yakugaku Zasshi 2006, 126, 1197-1203. [CrossRef]

16. Zakaria, Z.A.; Mohamed, A.M.; Mohd Jamil, N.S.; Rofiee, M.S.; Fatimah, C.A.; Mat Jais, A.M.; Sulaiman, M.R.; Somchit, M.N. In vitro anticancer activity of various extracts of the Malaysian, available but neglected, plants (Muntingia calabura and Dicranopteris linearis) against MCF-7 and HT-29 cancer cell lines. E-PharmaNexus 2008, 1, 10-17.

17. Zakaria, Z.A.; Mohamed, A.M.; Mohd Jamil, N.S.; Rofiee, M.S.; Somchit, M.N.; Zuraini, A.; Arifah, A.K.; Sulaiman, M.R. In vitro cytotoxic and antioxidant properties of the aqueous, chloroform and methanol extracts of Dicranopteris linearis leaves. Afr. J. Biotechnol. 2011, 10, 273-282.

18. Zakaria, Z.A.; Sodri, N.H.; Hassan, H.; Anuar, K.; Fatimah, C.A. Effects of various receptor antagonists on the peripheral antinociceptive activity of aqueous extracts of Dicranopteris linearis, Melastoma malabathricum and Bauhinia purpurea leaves in mice. TANG 2012, 2, e38. [CrossRef]

19. Zakaria, Z.A.; Abdul Ghani, Z.D.F.; Raden Mohd Nor, R.N.S.; Hanan Kumar, G.; Sulaiman, M.R.; Mat Jais, A.M.; Somchit, M.N.; Arifah, A.K.; Ripin, J. Antinociceptive, anti-inflammatory and antipyretic properties of Dicranopteris linearis leaves aqueous extract in experimental animals. J. Nat. Med. 2008, 62, 179-187. [CrossRef]

20. Md Tohid, S.F.; Zakaria, Z.A.; Baharuddin, A.A.; Roosli, R.A.J. Dicranopteris linearis extract Inhibits the proliferation of human breast cancer cell lines (MDA-MB-231) via induction of S-phase arrest and apoptosis. Pharm. Biol. 2018, 56, 422-432.

21. Shamsahal Din, S.; Mamat, S.S.; Ismail, N.A.; Wan Zainulddin, W.N.; Zabidi, Z.; Yahya, F.; Kamisan, F.H.; Mohtarrudin, N.; Othman, F.; Suhaili, Z.; et al. Effect of chloroform extract of Dicranopteris linearis leaves against paracetamol- and $\mathrm{CCl}_{4}$-induced liver toxicity in rats. TANG 2012, 2, e34. [CrossRef]

22. Mamat, S.S.; Kamisan, F.H.; Wan Zainulddin, W.N.; Ismail, N.A.; Yahya, F.; Shamsahal Din, S.; Zabidi, Z.; Mohtarrudin, N.; Arifah, A.K.; Zakaria, Z.A. Effect of methanol extract of Dicranopteris linearis leaves against paracetamol- and $\mathrm{CCl}_{4}$-induced liver toxicity in rats. J. Med. Plants Res. 2013, 7, 1305-1309.

23. Kamisan, F.H.; Yahya, F.; Mamat, S.S.; Kamarolzaman, M.F.F.; Suhaili, Z.; Mohtarrudin, N.; Ching, S.M.; Teh, L.K.; Salleh, M.Z.; Abdullah, M.N.H.; et al. Effect of methanol extract of Dicranopteris linearis against carbon tetrachloride-induced acute liver injury in rats. BMC Complement Altern. Med. 2014, 14, 123-132. [CrossRef] [PubMed]

24. Ismail, N.A.; Shamsahal Din, S.; Mamat, S.S.; Zabidi, Z.; Wan Zainulddin, W.N.; Kamisan, F.H.; Yahya, F.; Mohtarrudin, N.; Mohd Desa, M.N.; Zakaria, Z.A. Hepatotoxicity of the aqueous extract of Dicranopteris linearis leaves in rats. Pak. J. Pharm. Sci. 2014, 27, 831-835. [PubMed]

25. Zakaria, Z.A.; Kamisan, F.H.; Omar, M.H.; Mahmood, N.D.; Othman, F.; Hamid, S.S.A.; Somchit, M.N. Methanol extract of Dicranopteris linearis L. leaves impedes acetaminophen-induced liver intoxication partly by enhancing the endogenous antioxidant system. BMC Complement Altern. Med. 2017, 17, 271-284. [CrossRef] [PubMed]

26. Rodzi, R.; Cheah, Y.L.; Ooi, K.K.; Othman, F.; Mohtaruddin, N.; Tohid, S.F.; Suhaili, Z.; Zakaria, Z.A. Chemopreventive potential of methanol extract of Dicranopteris linearis leaf on DMBA/croton oil-induced mouse skin carcinogenesis. Afr. J. Pharm. Pharmacol. 2013, 7, 2484-2498. [CrossRef] 
27. Zakaria, Z.A.; Mohd Sani, M.H.; Kadir, A.A.; Kek, T.L.; Salleh, M.Z. Antinociceptive effect of semi-purified petroleum ether partition of Muntingia calabura leaves. Braz. J. Pharmacogn. 2016, 26, 408-419. [CrossRef]

28. Singleton, V.L., Jr.; Rossi, J.A. Colorimetry of total phenolics with phosphomolybdicphosphotungstic acid reagents. Am. J. Enol. Vitic. 1965, 16, 144-158.

29. Blois, M.S. Antioxidant determinations by the use of a stable free radical. Nature 1958, 181, 1199-1200. [CrossRef]

30. Nithianantham, K.; Shyamala, M.; Chen, Y.; Latha, L.Y.; Jothy, S.L.; Sasidharan, S. Hepatoprotective potential of Clitoria ternatea leaf extract against paracetamol induced damage in mice. Molecules 2011, 16, 10134-10145. [CrossRef]

31. Liu, F.; Ooi, V.E.; Chang, S.T. Free radical scavenging activities of mushroom polysaccharide extracts. Life Sci. 1997, 60, 763-771. [CrossRef]

32. Huang, D.; Ou, B.; Hampsch-Woodil, M.; Flanagan, J.A.; Prior, R.L. High throughput assay of oxygen radical absorbance capacity (ORAC) using a multichannel liquid handling system coupled with a microplate fluorescence reader in 96-well format. J. Agric. Food Chem. 2002, 50, 4437-4444. [CrossRef] [PubMed]

33. Malik, A.; Anis, I.; Khan, S.B.; Ahmed, E.; Ahmed, Z.; Nawaz, S.A. Enzymes inhibiting lignans from Vitex negundo. Chem. Pharm. Bull. 2004, 52, 1269-1272.

34. Orhan, E.I.; Sener, B.; Musharraf, S.G. Antioxidant and hepatoprotective activity appraisal of four selected Fumaria species and their total phenol and flavonoid quantities. Exp. Toxicol. Pathol. 2012, 64, 205-209. [CrossRef]

35. Lowry, O.H.; Rosebrough, N.J.; Farr, A.L.; Randall, R.J. Protein measurement with the Folin phenol reagent. J. Biol. Chem. 1951, 193, 265-275.

36. El-Beshbishy, H.A.; Mohamadin, A.M.; Nagy, A.A.; Abdel-Naim, A.B. Amelioration of tamoxifen-induced liver injury in rats by grape seed extract, black seed extract and curcumin. Indian J. Exp. Biol. 2010, 48, 280-288.

37. Ikhiri, K.; Boureima, D.; Dicko, D.; Koulodo, D. Chemical screening of medicinal plants used in the traditional pharmacopoeia of Niger. Int. J. Pharmacogn. 1992, 30, 251-262. [CrossRef]

38. Zakaria, Z.A.; Abdul Rahim, M.H.; Roosli, R.A.J.; Mohd Sani, M.H.; Omar, M.H.; Mohd. Tohid, S.F.; Othman, F.; Ching, S.M.; Abdul Kadir, A. Antinociceptive activity of methanolic extract of Clinacanthus nutans leaves: Possible mechanisms of action involved. Pain Res. Manag. 2018, 2018, 9536406. [CrossRef]

39. Pereira, D.M.; Valentão, P.; Pereira, J.A.; Andrade, P.B. Phenolics: From chemistry to biology. Molecules 2009, 14, 2202-2211. [CrossRef]

40. Lai, H.Y.; Lim, Y.Y. Evaluation of antioxidant activities of the methanolic extracts of selected ferns in Malaysia. Int. J. Environ. Sci. Dev. 2011, 2, 442-447. [CrossRef]

41. Gaspar-Marques, C.; Simões, M.F.; Valdeira, M.L.; Rodríguez, B. Terpenoids and phenolics from Plectranthus strigosus, bioactivity screening. Nat. Prod. Res. 2008, 22, 167-177. [CrossRef] [PubMed]

42. Sandjo, L.P.; Kuete, V. Chapter 4: Triterpenes and Steroids from the Medicinal Plants of Africa. In Medicinal Plant Research in Africa: Pharmacology and Chemistry, 1st ed.; Kuete, V., Ed.; Elsevier: London, UK, 2013; pp. 135-202. [CrossRef]

43. Russo, A.; Longo, R.; Vanella, A. Antioxidant activity of propolis: Role of caffeic acid phenethyl ester and galangin. Fitoterapia 2002, 73, S21-S29. [CrossRef]

44. Gülçin, I.; Mshvildadze, V.; Gepdiremen, A.; Elias, R. Antioxidant activity of saponins isolated from Ivy: $\alpha$-Hederin, hederasaponin-C, hederacolchiside-E and hederacolchiside-F. Planta Medica 2004, 70, 561-563. [CrossRef] [PubMed]

45. Amini, E.; Nabiuni, M.; Baharara, J.; Parivar, K.; Asili, J. Metastatic inhibitory and radical scavenging efficacies of saponins extracted from the Brittle Star (Ophiocoma erinaceus). Asian Pac. J. Cancer Prev. 2015, 16, 4751-4758. [CrossRef] [PubMed]

46. Liu, Y.Y.; Yang, Y.N.; Feng, Z.M.; Jiang, J.S.; Zhang, P.C. Eight new triterpenoid saponins with antioxidant activity from the roots of Glycyrrhiza uralensis Fisch. Fitoterapia 2019, 133, 186-192. [CrossRef] [PubMed]

47. Cichoż-Lach, H.; Michalak, A. Oxidative stress as a crucial factor in liver diseases. World J. Gastroenterol. 2014, 20, 8082-8091. [CrossRef] [PubMed]

48. Hohmann, M.S.; Cardoso, R.D.; Pinho-Ribeiro, F.A.; Crespigio, J.; Cunha, T.M.; Alves-Filho, J.C.; Silva, R.V.; Pinge-Filho, P.; Ferreira, S.H.; Cunha, F.Q.; et al. 5-lipoxygenase deficiency reduces acetaminophen-induced hepatotoxicity and lethality. BioMed Res. Int. 2013, 2013, 627046. [CrossRef] 
49. Li, L.; Liu, Y.R.; Gao, S.; Li, J.F.; Li, S.S.; Zhang, D.D.; Liu, S.; Bai, L.; Zheng, S.J.; Duan, Z.P.; et al. Inhibition of 5-lipoxygenase pathway attenuates acute liver failure by inhibiting macrophage activation. J. Immunol. Res. 2014, 2014, 697560. [CrossRef]

50. Pu, S.; Ren, L.; Liu, Q.; Kuang, J.; Shen, J.; Cheng, S.; Zhang, Y.; Jiang, W.; Zhang, Z.; Jiang, C.; et al. Loss of 5-lipoxygenase activity protects mice against paracetamol-induced liver toxicity. Br. J. Pharmacol. 2015, 173, 66-76. [CrossRef]

51. Ichimori, K.; Fukahori, M.; Nakazawa, H.; Okamoto, K.; Nishino, T. Inhibition of xanthine oxidase and xanthine dehydrogenase by nitric oxide. J. Biol. Chem. 1999, 274, 7763-7768. [CrossRef]

52. Jaeschke, H. Glutathione disulfide formation and oxidant stress during acetaminophen-induced hepatotoxicity in mice in vivo: The protective effect of allopurinol. J. Pharmacol. Exp. Ther. 1990, 255, 935-941. [PubMed]

53. Williams, C.D.; McGill, M.R.; Lebofsky, M.; Bajt, M.L.; Jaeschke, H. Protection against acetaminophen-induced liver injury by allopurinol is dependent on aldehyde oxidase-mediated liver preconditioning. Toxicol. Appl. Pharmacol. 2014, 274, 417-424. [CrossRef] [PubMed]

54. Du, K.; Ramachandran, A.; Jaeschke, H. Oxidative stress during acetaminophen hepatotoxicity: Sources, pathophysiological role and therapeutic potential. Redox Biol. 2016, 10, 148-156. [CrossRef] [PubMed]

55. Guay, J.; Bateman, K.; Gordon, R.; Mancini, J.; Riendeau, D. Carrageenan-induced paw edema in rat elicits a predominant prostaglandin $\mathrm{E}_{2}\left(\mathrm{PGE}_{2}\right)$ response in the central nervous system associated with the induction of microsomal PGE 2 synthase-1. J. Biol. Chem. 2004, 279, 24866-24872. [CrossRef]

56. Reilly, T.P.; Brady, J.N.; Marchick, M.R.; Bourdi, M.; George, J.W.; Radonovich, M.F.; Pise-Masison, C.A.; Pohl, L.R. A protective role for cyclooxygenase-2 in drug-induced liver injury in mice. Chem. Res. Toxicol. 2001, 14, 1620-1628. [CrossRef]

57. Suciu, M.; Gruia, A.T.; Nica, D.V.; Azghadi, S.M.; Mic, A.A.; Mic, F.A. Acetaminophen-induced liver injury: Implications for temporal homeostasis of lipid metabolism and eicosanoid signaling pathway. Chem. Biol. Interact. 2015, 242, 335-344. [CrossRef]

58. Tittarelli, R.; Pellegrini, M.; Scarpellini, M.G.; Marinelli, E.; Bruti, V.; Di Luca, N.M.; Busardo, F.P.; Zaami, S. Hepatotoxicity of paracetamol and related fatalities. Eur. Rev. Med. Pharmacol. Sci. 2017, 21, 95-101.

59. Giannini, E.G.; Testa, R.; Savarino, V. Liver enzyme alteration: A guide for clinicians. Can. Med. Assoc. J. 2005, 172, 367-369. [CrossRef]

60. Sharma, P.; Gupta, M.; Goya, G.; Kaur, K. Serum enzymes in hepatobiliary carcinoma. J. Evol. Med. Dent. Sci. 2014, 3, 2236-2244. [CrossRef]

61. Sharma, U.; Pal, D.; Prasad, R. Alkaline phosphatase: An overview. Indian J. Clin. Biochem. 2014, 29, $269-278$. [CrossRef]

62. Ighodaro, O.M.; Akinloye, O.A. First line defence antioxidants-superoxide dismutase (SOD), catalase (CAT) and gluta thione peroxidase (GPX): Their fundamental role in the entire antioxidant defence grid. Alex. J. Med. 2018, 54, 287-293. [CrossRef]

63. Stefova, M.; Stafilov, T.; Kulevanova, S. HPLC analysis of flavonoid. In Encyclopedia of Chromatography, 1st ed.; Cazes, J., Ed.; Marcel Dekker, Inc.: New York, NY, USA, 2003; pp. 1-7.

64. Tsimogiannis, D.; Samiotaki, M.; Panayotou, G.; Oreopoulou, V. Characterization of flavonoid subgroups and hydroxy substitution by HPLC-MS/MS. Molecules 2007, 12, 593-606. [CrossRef] [PubMed]

65. Raja, D.P.; Manickam, V.S.; de Britto, A.J.; Gopalakrishnan, S.; Ushioda, T.; Satoh, M.; Tanimura, A.; Fuchino, H.; Tanaka, N. Chemical and chemotaxonomical studies on Dicranopteris species. Chem. Pharm. Bull. 1995, 43, 1800-1803. [CrossRef] [PubMed]

66. Chen, J.; Chen, J.J.; Gao, K. Chemical constituents and biological activities of Dicranopteris linearis. Chem. Nat. Compd. 2014, 49, 1129-1131. [CrossRef]

67. Ponnusamy, Y.; Chear, N.J.; Ramanathan, S.; Lai, C.S. Polyphenols rich fraction of Dicranopteris linearis promotes fibroblast cell migration and proliferation in vitro. J. Ethnopharmacol. 2015, 168, 305-314. [CrossRef] [PubMed]

68. Shehab, N.G.; Abu-Gharbieh, E.; Bayoumi, F.A. Impact of phenolic composition on hepatoprotective and antioxidant effects of four desert medicinal plants. BMC Complement Altern. Med. 2015, 15, 401-412. [CrossRef] [PubMed] 
69. Qu, L.; Xin, H.; Zheng, G.; Su, Y.; Ling, C. Hepatoprotective activity of the total saponins from Actinidia valvata Dunn root against carbon tetrachloride-induced liver damage in mice. Evid. Based Complement Altern. Med. 2012, 2012, 216061. [CrossRef]

70. Wang, Y.G.; Ma, Q.G.; Tian, J.; Ren, J.; Wang, A.G.; Ji, T.F.; Yang, J.B.; Su, Y.L. Hepatoprotective triterpenes the gum resin of Boswellia carterii. Fitoterapia 2016, 109, 266-273. [CrossRef]

(C) 2019 by the authors. Licensee MDPI, Basel, Switzerland. This article is an open access article distributed under the terms and conditions of the Creative Commons Attribution (CC BY) license (http://creativecommons.org/licenses/by/4.0/). 